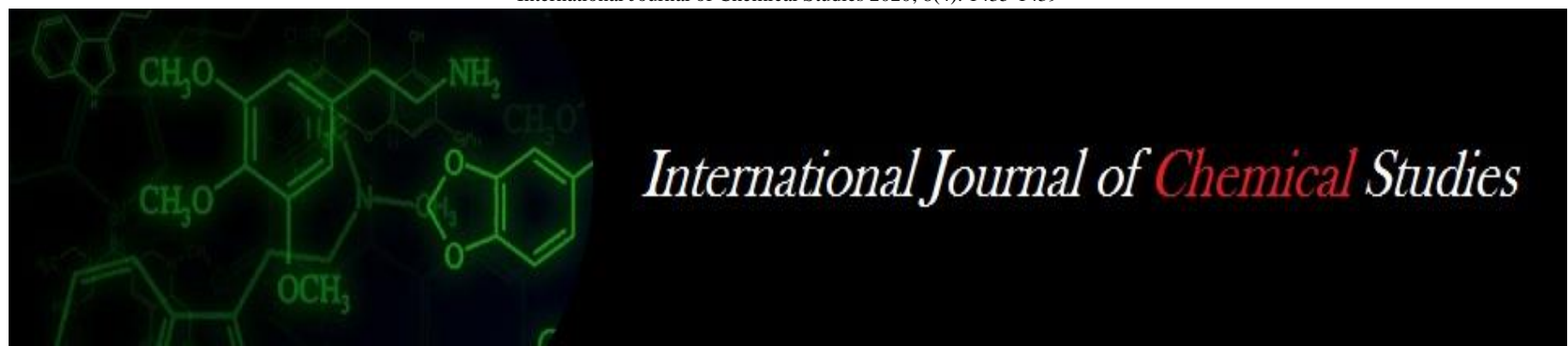

P-ISSN: 2349-8528

E-ISSN: 2321-4902

www.chemijournal.com

IJCS 2020; 8(4): 1435-1439

(C) 2020 IJCS

Received: 22-05-2020

Accepted: 24-06-2020

Viswanadha Raghuteja Puvvala Ph.D. Scholar, Department of Entomology, College of Horticulture, Dr. Y.S.R. Horticultural University, Venkataramannagudem, Andhra Pradesh, India
Corresponding Author: Viswanadha Raghuteja Puvvala Ph.D. Scholar, Department of Entomology, College of Horticulture, Dr. Y.S.R. Horticultural University, Venkataramannagudem, Andhra Pradesh, India

\section{Multi residue analysis of insecticides in okra (Abelmoschus esculentus (L.) monech) fruits of tadepalligudem market, west Godavari district, Andhra Pradesh, India}

\section{Viswanadha Raghuteja Puvvala}

DOI: https://doi.org/10.22271/chemi.2020.v8.i4m.9816

\begin{abstract}
Levels of pesticide residues in the okra fruits obtained from local tadepalligudem market was estimated at Pesticide Residue and Food Quality Analysis Laboratory (PRFQAL), University of Agricultural Sciences, Raichur, Karnataka. As sample of okra fruits were collected from tadepalligudem market and analyzed for multiresidues. Surprisingly, out of 74 chemicals tested, profenophos with $0.048 \mathrm{ppm}$ was detected which was above the Maximum Residual Limit (MRL) of $0.01 \mathrm{ppm}$.
\end{abstract}

Keywords: okra, PRFQAL, multiresidues and MRL

\section{Introduction}

Pesticides, such as insecticides, herbicides, fungicides and acaricides, have been widely applied during the cultivation and the post-harvest storage of crops. These pesticides were used to prevent the destruction of edible crops by controlling agricultural pests or unwanted plants and thereby increases and improve food production.

Okra (Abelmoschus esculentus (L.) Moench) is originated in Africa, is one of the important vegetable crops and placed in under Malvaceae family. It is rich source of dietary fiber, antioxidants, ascorbic acid and folate. Mucilage from okra has been reported to be effective as blood volume expander and has the potential to alleviate renal disease, reduce proteinuria and improve renal function (Siemonsma and Kouame, 2004) ${ }^{[4]}$. The production and productivity of okra is limited by incidence of various pests.

Indiscriminate use of pesticides to manage the pest complex in bhendi and negligence to follow proper waiting periods make marketed produce with toxic pesticides and may pose health hazards to consumers (Lakshminarayana and Menon, 1975 and Mukherjee and Gopal, 2003) $[2,3]$. The presence of insecticide residues viz., flubendiamide $(0.142 \mathrm{mg} / \mathrm{kg})$, profenophos $(0.042 \mathrm{mg} / \mathrm{kg})$, acephate $(0.193 \mathrm{mg} / \mathrm{kg})$, fipronil $(0.028 \mathrm{mg} / \mathrm{kg})$, chlorpyrifos $(0.275 \mathrm{mg} / \mathrm{kg})$, lambda-cyhalothrin $(0.241 \mathrm{mg} / \mathrm{kg})$, acetamiprid $(0.167 \mathrm{mg} / \mathrm{kg})$, monocrotophos $(0.011 \mathrm{mg} / \mathrm{kg})$, and imidacloprid $(0.032 \mathrm{mg} / \mathrm{kg})$ were found in the okra samples collected from Rythu bazaar vegetable market of karimnagar during 2014-15 and these pesticide residues find their way into the human body through food, water, and environment. Among the samples analyzed for different insecticide residues, two of the insecticides i.e., chlorpyriphos and acetamiprid have shown above MRL value established by Codex alimentarius, while the remaining insecticide residues detected in the samples were below the MRL (Anil et al., 2017) [1].

Materials and methods

A sample of $1 \mathrm{Kg}$ okra fruits were collected from tadepalligudem market and analyzed for residues by using Liquid Chromatography-Mass Spectrophotometry (LC-MS/MS) and Gas Chromatography-Mass Spectrophotometry (GC-MS/MS). The analysis was undertaken at Pesticide Residue and Food Quality Analysis Laboratory (PRFQAL), University of Agricultural Sciences, Raichur, Karnataka. The following methods were adopted for estimation of insecticide residues in okra fruits of tadepalligudem market. 
Steps involved in the estimation of insecticide residues sample of okra from Tadepalligudem market, West Godavari District, Andhra Pradesh.

\section{A. Extraction}

Okra fruits were chopped into small pieces and blended in the grinder. The fortified sample $(10 \mathrm{~g})$ was taken in a $50 \mathrm{ml}$ centrifuge tube and added with $5 \mathrm{ml}$ distilled water. After 30 min, the blended mixture was added with $10 \mathrm{ml}$ ethyl acetate and $10 \mathrm{~g}$ anhydrous sodium sulphate (activated at $500{ }^{\circ} \mathrm{C}$ for 4 hours).

\section{B. Homogenization}

After extraction, the sample mixture was homogenized at 10000-13000 rpm for 3 minutes.

\section{High volume centrifugation}

The content was subjected to high volume centrifugation at $5000 \mathrm{rpm}$ for 5 minutes at $10^{\circ} \mathrm{C}$.

\section{Clean up}

After centrifugation, $7 \mathrm{ml}$ of extract was transferred to $15 \mathrm{ml}$ centrifuge tube containing $25 \mathrm{mg}$ of primary secondary amine (PSA) and $150 \mathrm{mg}$ of magnesium sulphate $\left(\mathrm{MgSO}_{4}\right)$. The mixture was homogenized in vortex for $1 \mathrm{~min}$ and centrifuged again at $12000 \mathrm{rpm}$ for 5 minutes followed by the addition of $25 \mathrm{mg}$ of activated charcoal for the removal of coloured impurities.

\section{E. Evaporation}

After clean up, $3 \mathrm{ml}$ of extract was transferred into two test tubes containing $300 \mu \mathrm{l}$ of 10 per cent diethylene glycol in methanol and evaporated to dryness using nitrogen concentrator at $35^{\circ} \mathrm{C}$ temperature. The residue was reconstituted for Liquid Chromatography-Mass Spectrophotometry (LC-MS) analysis with $1.5 \mathrm{ml}$ LC compatible solvent (methanol). The mixture was homogenized in vortex for 30 seconds and sonicated for one minute to dissolve the residues.

\section{F. Filtration}

The extract of $1.5 \mathrm{ml}$ was then filtered to LC autosampler vials through $0.22 \mu$ Poly tetra fluoro ethylene (PTFE) membrane filter. These steps involved are presented in plate 1.

\section{G. Sample Injection}

Sample of $2 \mu \mathrm{l}$ filtrate was injected into LC-MS/MS with below conditions.

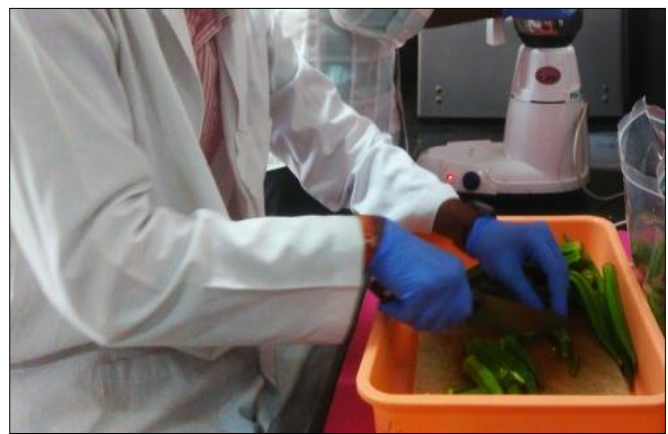

Chopping of okra fruits

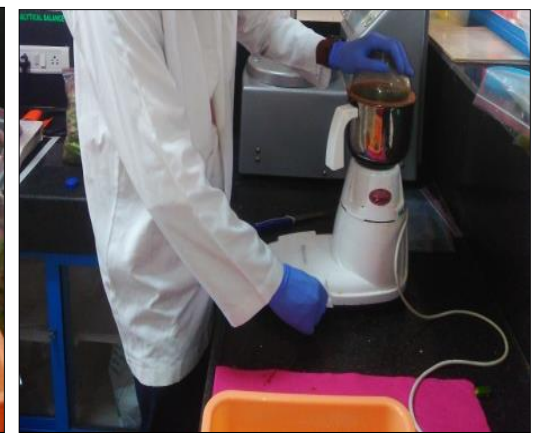

Blending in a grinder

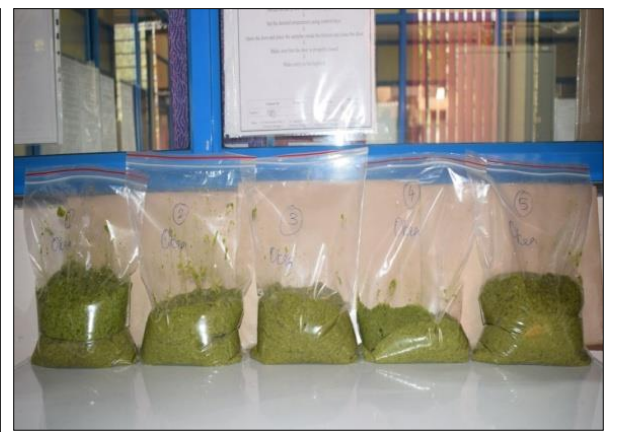

Blended mixture

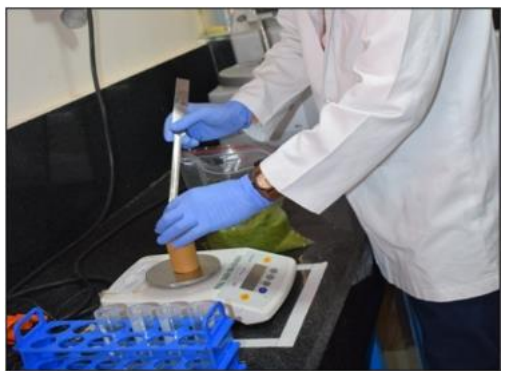

$10 \mathrm{gm}$ of blended mixture was taken

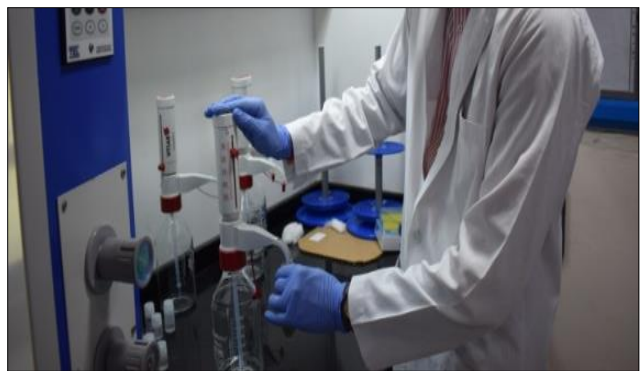

Addition of $10 \mathrm{ml}$ ethyl acetate

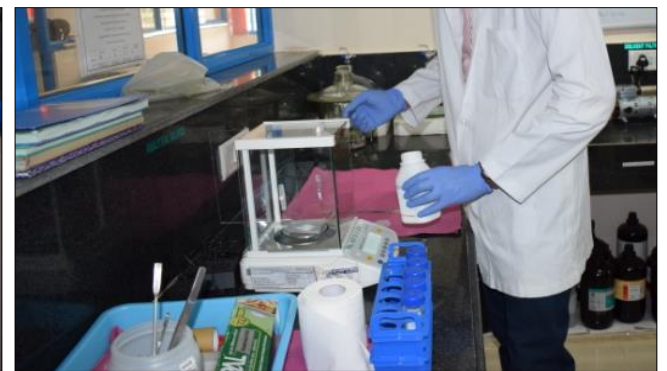

Weighing of $10 \mathrm{~g}$ anhydrous $\mathrm{Na}_{2} \mathrm{SO}_{4}$

Plate 1: Steps involved in pesticide residue analysis.........contd

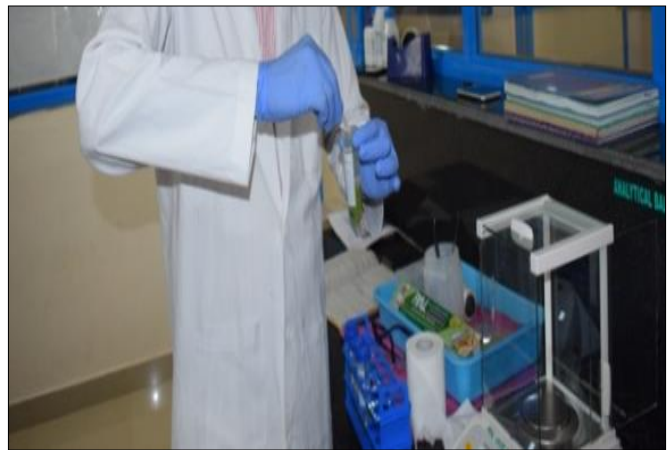

Addition of $10 \mathrm{~g}$ anhydrous $\mathrm{Na}_{2} \mathrm{SO}_{4}$

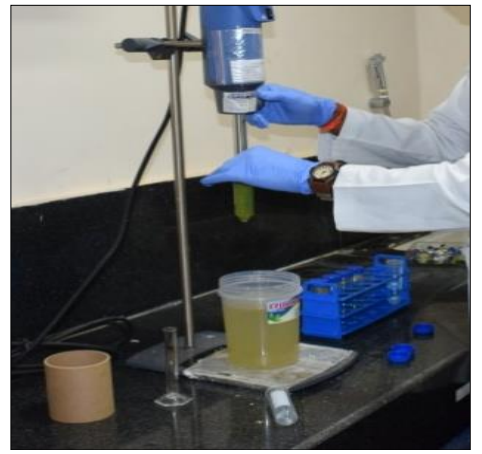

Addition of $10 \mathrm{~g}$ anhydrous $\mathrm{Na}_{2} \mathrm{SO}_{4}$

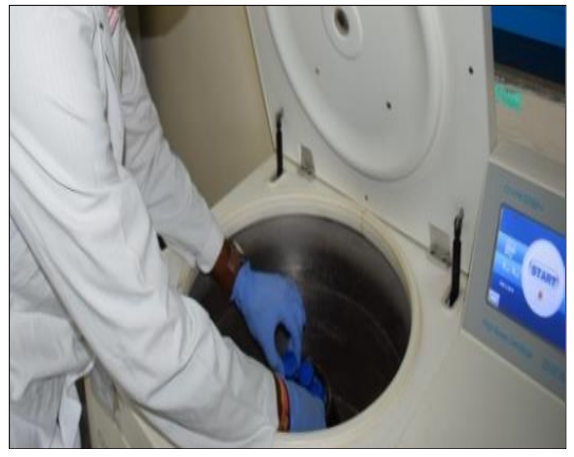

High Volume

Centrifugation 

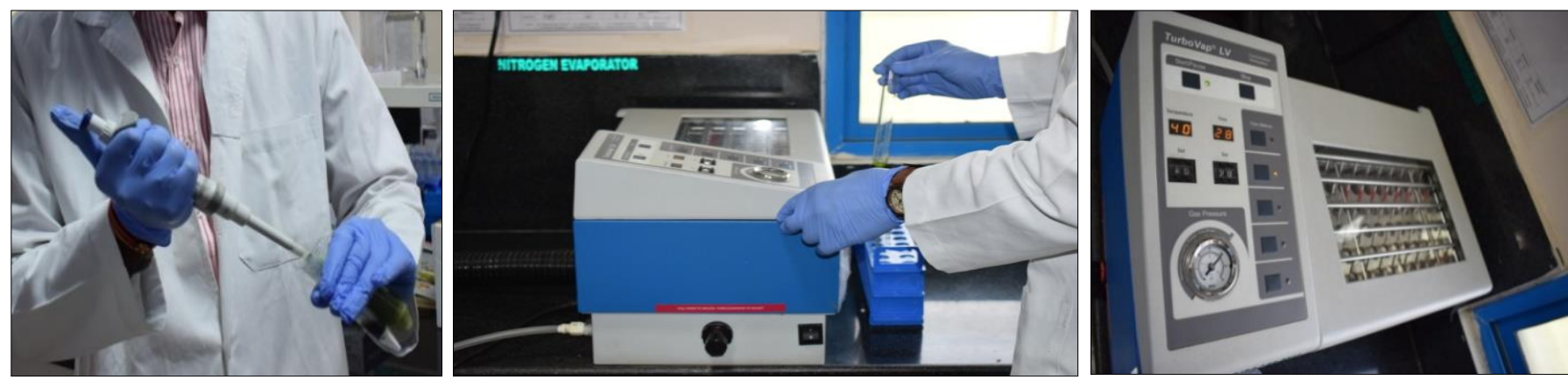

Transfer of $7 \mathrm{ml}$ extract to $15 \mathrm{ml}$ centrifuge tube containing $25 \mathrm{mg}$

PSA and $150 \mathrm{mg} \mathrm{MgSO}_{4}$

Homogenization, high volume centrifugation, evaporating to dryness using nitrogen concentrator

\section{H. Analysis of pesticide residue}

The sample was analyzed using Liquid ChromatographyMass Spectrophotometry (LC-MS/MS) to determine the residual content. LC was equipped with mega bore column Shimpack XR with dimensions $2 \mathrm{~mm}$ id $\mathrm{x} 150 \mathrm{~mm}$. The working conditions were as follows: ECI probe source, total run time $25 \mathrm{~min}$, Nitrogen gas flow rate $0.4 \mathrm{ml}$ per minute, Heart block temperature $400^{\circ} \mathrm{C}$ and dissolution temperature $200^{\circ} \mathrm{C}$. Nebulizing and Drying gas flow (Nitrogen) rate of 2.9 $1 / \mathrm{min}$ and $15 \mathrm{l} / \mathrm{min}$. The mobile phase was $0.0314 \mathrm{~g}$ ammonium formate $(5 \mathrm{mM})+2 \mathrm{ml}$ methanol $+10 \mu$ formic acid $(0.01 \%)$ made up the volume with HPLC water to $100 \mathrm{ml}$ (or) $0.0314 \mathrm{~g}$ ammonium formate $(5 \mathrm{mM})+10 \mu 1$ formic acid $(0.01 \%)$ made up the volume with $100 \%$ methanol to $100 \mathrm{ml}$. GC was equipped with column HP-5 MS with dimensions of $0.25 \mu$ film thickness, $30 \mathrm{~m}$ length. The working conditions were as follows: Total run time $41.07 \mathrm{~min}$, total flow rate 4.5 $\mathrm{ml}$ per minute, column flow rate $1.5 \mathrm{ml}$ per minute, mass range 50 to 550 , injector temperature $280^{\circ} \mathrm{c}$, transfer line temperature $280^{\circ} \mathrm{c}$, source temperature $300^{\circ} \mathrm{c}$.

\section{Method validation}

Blank samples of okra were analyzed to verify the absence of interfering species. The matrix-dependent limit of detection (LOD) and limits of quantification (LOQ) was calculated for analytical methodology using the blank and calibration standards of okra. The LOD value of insecticide is the concentration that produces a signal to noise (peak to peak) ratio of 3. The LOQ is defined based on the signal-to-noise ratio of 10 and estimated from the chromatogram to the lowest point used in the matrix-matched calibration. The retention time was noted.
Calculation: The recovery (\%) and residues from the fortified sample were calculated by using the following formula.

$$
\begin{gathered}
\text { Recovery }(\%)=\frac{\text { Concentration of fortified sample }(\mathrm{mg} / \mathrm{kg})}{\text { Concentration of analytical standard of pesticide }} \times 100 \\
\text { Residue }(\mathrm{mg} / \mathrm{kg})=\frac{\text { Peak area of sample } \times \text { Conc. of Std. } \times \mu l \text { std. injected }}{\begin{array}{l}
\text { Final volume of sample }(1.5 \mathrm{ml}) \times \text { Peak area }(\text { standard }) \\
\times \text { weight of the sample }(\mathrm{g}) \times \mu 1 \text { sample injected }
\end{array}} \\
\text { Weight of sample }(\mathrm{g})=\frac{\text { Sample weight } \mathrm{x} \text { aliquot taken }(\mathrm{ml})}{\text { Volume of extractant }(\mathrm{ml})}
\end{gathered}
$$

\section{Results and discussion}

The farm gate sample of okra fruits were collected from tadepalligudem market and analyzed for residues to detect 74 chemicals using Liquid Chromatography - Mass Spectrophotometry/Mass Spectrophotometry (LC-MS/MS) and Gas Chromatography-Mass Spectrophotometry/Mass Spectrophotometry (GC-MS/MS).

Among the 74 chemicals tested for residues, okra fruits were observed to be contaminated with profenophos $(0.048 \mathrm{ppm})$, which was above maximum residue limits (MRL) of 0.01 ppm (table 1). Similar reports were made by Anil et al. (2017) ${ }^{[1]}$ who detected residues of profenophos from Rythu bazaar market $(0.042 \mathrm{mg} / \mathrm{kg})$, Tower circle $(0.065 \mathrm{mg} / \mathrm{kg})$ and Ramnagar vegetable market $(0.052 \mathrm{mg} / \mathrm{kg})$ of karimnagar. While spinosad, emmamectin benzoate, tetraconazole, propanil, chlorpyriphos methyl and cypermethrin were below quantification level (BQL), while the remaining chemicals were not detected in the sample. The LC-MS/MS chromatogram is presented in plate 2 .

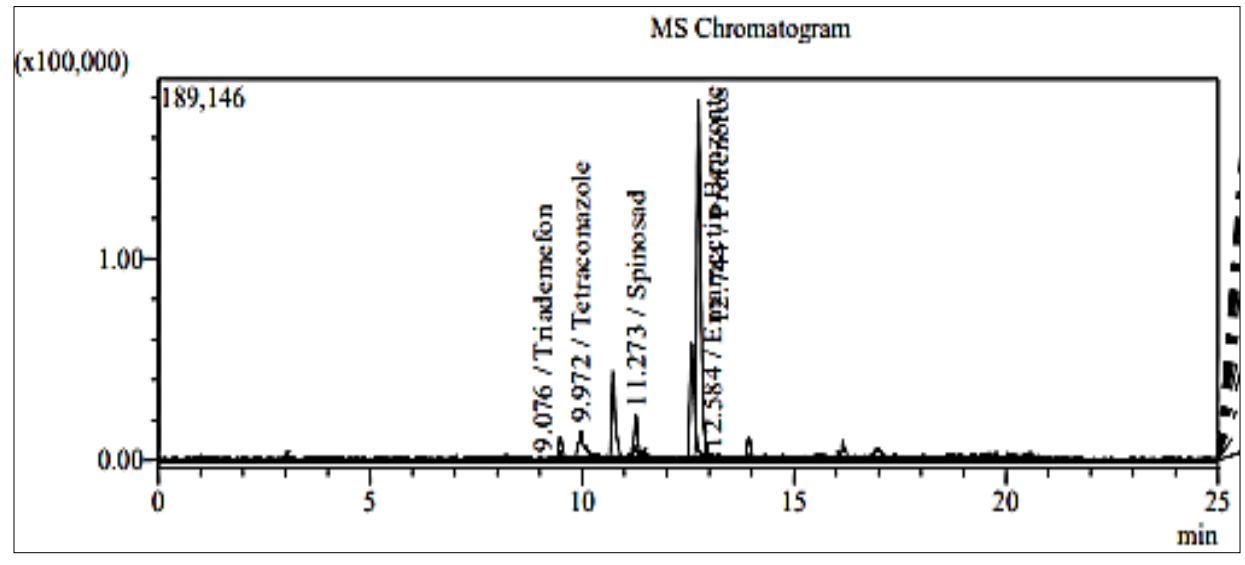

Plate 2: LC-MS Chromatogram of okra market sample for 39 pesticides 


\section{Conclusion}

The present pattern of insecticides detected in the okra sample collected from tadepalligudem market does not seem to contribute toward excessive residues. However, the insecticides should be applied in a need based manner and recommended insecticides should be applied as and when required. Further to safeguard the consumer's interest, proper waiting period must be practiced by the producer before marketing vegetables.

\section{Acknowledgement}

The author is thankful to Dr. Rajasekhar garu, Assistant Director, Animal husbandary, Kadapa District, Andhra Pradesh, India for providing me necessary facilities. The authors are also thankful to Dr. Harish Chandra. R. Naik and Dr. Bhemmana of Pesticide Residue and Food Quality Analysis Laboratory (PRFQAL), University of Agricultural Sciences, Raichur, Karnataka.

Table 1: Insecticide residues detected in okra fruits grown in Tadepalligudem (West Godavari district, Andhra Pradesh) market

\begin{tabular}{|c|c|c|c|c|}
\hline S. No. & Name of the sample & Result & Unit & Method of Analysis/technique \\
\hline 1. & Thiachloprid & ND & $\mathrm{mg} / \mathrm{kg}$ & LC-MS/MS \\
\hline 2. & Buprofezin & ND & $\mathrm{mg} / \mathrm{kg}$ & LC-MS/MS \\
\hline 3. & Methalachlor & ND & $\mathrm{mg} / \mathrm{kg}$ & LC-MS/MS \\
\hline 4. & Imidachloprid & ND & $\mathrm{mg} / \mathrm{kg}$ & LC-MS/MS \\
\hline 5. & Dimethoate & ND & $\mathrm{mg} / \mathrm{kg}$ & LC-MS/MS \\
\hline 6. & Coumatetryl & ND & $\mathrm{mg} / \mathrm{kg}$ & LC-MS/MS \\
\hline 7. & Triademeneol & ND & $\mathrm{mg} / \mathrm{kg}$ & LC-MS/MS \\
\hline 8. & Triademefon & ND & $\mathrm{mg} / \mathrm{kg}$ & LC-MS/MS \\
\hline 9. & Thiodicarb & ND & $\mathrm{mg} / \mathrm{kg}$ & LC-MS/MS \\
\hline 10. & Spinosad & BQL & $\mathrm{mg} / \mathrm{kg}$ & LC-MS/MS \\
\hline 11. & Phosalone & ND & $\mathrm{mg} / \mathrm{kg}$ & LC-MS/MS \\
\hline 12. & Methoxyfenozide & ND & $\mathrm{mg} / \mathrm{kg}$ & LC-MS/MS \\
\hline 13. & Hexythiazox & ND & $\mathrm{mg} / \mathrm{kg}$ & LC-MS/MS \\
\hline 14. & Fenpyroximate & ND & $\mathrm{mg} / \mathrm{kg}$ & LC-MS/MS \\
\hline 15. & Carbendazim & ND & $\mathrm{mg} / \mathrm{kg}$ & LC-MS/MS \\
\hline 16. & Carbaryl & ND & $\mathrm{mg} / \mathrm{kg}$ & LC-MS/MS \\
\hline 17. & Triazophos & ND & $\mathrm{mg} / \mathrm{kg}$ & LC-MS/MS \\
\hline 18. & Carbofuran & ND & $\mathrm{mg} / \mathrm{kg}$ & LC-MS/MS \\
\hline 19. & Bitertenol & ND & $\mathrm{mg} / \mathrm{kg}$ & LC-MS/MS \\
\hline 20. & Bendiocarb & ND & $\mathrm{mg} / \mathrm{kg}$ & LC-MS/MS \\
\hline 21. & Benalaxyl & ND & $\mathrm{mg} / \mathrm{kg}$ & LC-MS/MS \\
\hline 22. & Acephate & ND & $\mathrm{mg} / \mathrm{kg}$ & LC-MS/MS \\
\hline 23. & Pymetrozine & ND & $\mathrm{mg} / \mathrm{kg}$ & LC-MS/MS \\
\hline 24. & Omethoate & ND & $\mathrm{mg} / \mathrm{kg}$ & LC-MS/MS \\
\hline 25. & Metribuzin & ND & $\mathrm{mg} / \mathrm{kg}$ & LC-MS/MS \\
\hline 26. & Metalaxyl & ND & $\mathrm{mg} / \mathrm{kg}$ & LC-MS/MS \\
\hline 27. & Isoproturon & ND & $\mathrm{mg} / \mathrm{kg}$ & LC-MS/MS \\
\hline 28. & Emmamectin benzoate & BQL & $\mathrm{mg} / \mathrm{kg}$ & LC-MS/MS \\
\hline 29. & Tetraconazole & BQL & $\mathrm{mg} / \mathrm{kg}$ & LC-MS/MS \\
\hline 30. & Quinalphos & ND & $\mathrm{mg} / \mathrm{kg}$ & LC-MS/MS \\
\hline 31. & Profenofos & 0.048 & $\mathrm{mg} / \mathrm{kg}$ & LC-MS/MS \\
\hline 32. & Phosphomidon & ND & $\mathrm{mg} / \mathrm{kg}$ & LC-MS/MS \\
\hline 33. & Pendimethaliun & ND & $\mathrm{mg} / \mathrm{kg}$ & LC-MS/MS \\
\hline 34. & Difenconazole & ND & $\mathrm{mg} / \mathrm{kg}$ & LC-MS/MS \\
\hline 35. & Pretilachlor & ND & $\mathrm{mg} / \mathrm{kg}$ & LC-MS/MS \\
\hline 36. & Penconazole & ND & $\mathrm{mg} / \mathrm{kg}$ & LC-MS/MS \\
\hline 37. & Paclobutrazole & ND & $\mathrm{mg} / \mathrm{kg}$ & LC-MS/MS \\
\hline 38. & Hexaconazole & ND & $\mathrm{mg} / \mathrm{kg}$ & LC-MS/MS \\
\hline 39. & Chlorantraniliprole & ND & $\mathrm{mg} / \mathrm{kg}$ & LC-MS/MS \\
\hline 40. & Phenol, 4- bromo 2- chloro & ND & $\mathrm{mg} / \mathrm{kg}$ & GC-MS/MS \\
\hline 41. & Trifluralin & ND & $\mathrm{mg} / \mathrm{kg}$ & GC-MS/MS \\
\hline 42. & Alpha-BHC & ND & $\mathrm{mg} / \mathrm{kg}$ & GC-MS/MS \\
\hline 43. & Beta-BHC & ND & $\mathrm{mg} / \mathrm{kg}$ & GC-MS/MS \\
\hline 44. & Diazinone & ND & $\mathrm{mg} / \mathrm{kg}$ & GC-MS/MS \\
\hline 45. & Fluchloralin & ND & $\mathrm{mg} / \mathrm{kg}$ & GC-MS/MS \\
\hline 46. & Tri-allate & ND & $\mathrm{mg} / \mathrm{kg}$ & GC-MS/MS \\
\hline 47. & Iprobenfos & ND & $\mathrm{mg} / \mathrm{kg}$ & GC-MS/MS \\
\hline 48. & Propanil & BQL & $\mathrm{mg} / \mathrm{kg}$ & GC-MS/MS \\
\hline 49. & Clorpyriphos methyl & $\mathrm{BQL}$ & $\mathrm{mg} / \mathrm{kg}$ & GC-MS/MS \\
\hline 50. & Parathion methyl & ND & $\mathrm{mg} / \mathrm{kg}$ & GC-MS/MS \\
\hline 51. & Alachlor & ND & $\mathrm{mg} / \mathrm{kg}$ & GC-MS/MS \\
\hline 52. & Heptachlor & ND & $\mathrm{mg} / \mathrm{kg}$ & GC-MS/MS \\
\hline 53. & Fenitrothion & ND & $\mathrm{mg} / \mathrm{kg}$ & GC-MS/MS \\
\hline 54. & Chlorpyriphos & ND & $\mathrm{mg} / \mathrm{kg}$ & GC-MS/MS \\
\hline 55. & Parathion & ND & $\mathrm{mg} / \mathrm{kg}$ & GC-MS/MS \\
\hline 56. & Chlorfenvinphos & ND & $\mathrm{mg} / \mathrm{kg}$ & GC-MS/MS \\
\hline
\end{tabular}




\begin{tabular}{|l|c|c|c|c|}
\hline 57. & Parathion & ND & $\mathrm{mg} / \mathrm{kg}$ & GC-MS/MS \\
\hline 58. & Butachlor & ND & $\mathrm{mg} / \mathrm{kg}$ & GC-MS/MS \\
\hline 59. & p, p'-DDE & ND & $\mathrm{mg} / \mathrm{kg}$ & GC-MS/MS \\
\hline 60. & Endrin & ND & $\mathrm{mg} / \mathrm{kg}$ & GC-MS/MS \\
\hline 61. & Beta-Endosulfon & ND & $\mathrm{mg} / \mathrm{kg}$ & GC-MS/MS \\
\hline 62. & p,p'-DDT & ND & $\mathrm{mg} / \mathrm{kg}$ & GC-MS/MS \\
\hline 63. & o,p'-DDT & ND & $\mathrm{mg} / \mathrm{kg}$ & GC-MS/MS \\
\hline 64. & Endosulfon sulphate & ND & $\mathrm{mg} / \mathrm{kg}$ & GC-MS/MS \\
\hline 65. & Bifenthrin & ND & $\mathrm{mg} / \mathrm{kg}$ & GC-MS/MS \\
\hline 66. & Fenpropathrin & ND & $\mathrm{mg} / \mathrm{kg}$ & GC-MS/MS \\
\hline 67. & Lamda-cyhalothrin & ND & $\mathrm{mg} / \mathrm{kg}$ & GC-MS/MS \\
\hline 68. & Permethrin & ND & $\mathrm{mg} / \mathrm{kg}$ & GC-MS/MS \\
\hline 69. & Cyfluthrin & ND & $\mathrm{mg} / \mathrm{kg}$ & GC-MS/MS \\
\hline 70. & Cypermethrin & BQL & $\mathrm{mg} / \mathrm{kg}$ & GC-MS/MS \\
\hline 71. & Ethofenprox & ND & $\mathrm{mg} / \mathrm{kg}$ & GC-MS/MS \\
\hline 72. & Fenvelerate & ND & $\mathrm{mg} / \mathrm{kg}$ & GC-MS/MS \\
\hline 73. & Deltamethrin & ND & $\mathrm{mg} / \mathrm{kg}$ & GC-MS/MS \\
\hline 74. & Aldrin & ND & $\mathrm{mg} / \mathrm{kg}$ & \\
\hline
\end{tabular}

N.D - Not Detected,

B.Q.L - Below Quantification Level ( $<0.01 \mathrm{mg} / \mathrm{kg})$,

LC-MS/MS - Liquid Chromatography - Mass

Spectrophotometry,

GC-MS/MS - Gas Chromatography - Mass

Spectrophotometry.

\section{References}

1. Anil KB, Ragini K, Padmasri A, Jeevan RK, Shashibhushan V. Monitoring of pesticide residues in okra (Abelmoschus esculentus L.) Agriculture Update. 2017; 12(7):1909-13.

2. Lakshminarayana V, Menon PK. Screening of Hyderabad market samples of food stuffs for organochlorine residues. Indian Journal Plant Protection. 1975; 3:4-19.

3. Mukherjee I, Gopal. Pesticide residues in vegetables in and around Delhi. Environment Monitoring \& Assessment. 2013; 86(3):265-71.

4. Siesmonsma JS, Kouame C. Vegetables. In: Plant resources of tropical Africa 2 (Grubben GJH \& Denton OA Eds.) PROTA Foundation, Wageningen, Agriculture and Biological Journal of North America. 2004; 4(5):532-38. 